\title{
Upington disease
}

INSERM

\section{Source}

INSERM. (1999). Orphanet: an online rare disease and orphan drug data base. Upington

disease. ORPHA:3408

Upington disease is characterised by Perthes-like pelvic anomalies (premature closure of the capital femoral epiphyses and widened femoral necks with flattened femoral heads), enchondromata and ecchondromata. It has been described in siblings from three generations of one family. Transmission is autosomal dominant. 